\title{
Pemanfaatan Multiplex Nested Polymerase Chain Reaction untuk Deteksi Patogen Penyebab Infeksi Kongenital
}

\author{
Utilization of Multiplex Nested Polymerase Chain Reaction for Detection of \\ Pathogens Causing Congenital Infections
}

\author{
Patricia Gita Naully ${ }^{1}$ dan R. Noucie Septriliyana ${ }^{2}$ \\ ${ }^{1}$ Teknologi Laboratorium Medik (D-4), Fakultas Ilmu dan Teknologi Kesehatan, UNJANI \\ ${ }^{2}$ Kebidanan (S-1) dan Profesi Bidan, Fakultas Ilmu dan Teknologi Kesehatan, UNJANI
}

\begin{abstract}
ABSTRAK
Latar Belakang: Salah satu penyebab tingginya angka kematian bayi di Kabupaten Bandung adalah infeksi kongenital seperti Toxoplasma gondii, Cytomegalovirus (CMV), dan Herpes Simplex Virus (HSV). Untuk menurunkan angka tersebut dibutuhkan metode deteksi yang sensitif dan spesifik. Salah satu metode yang dapat digunakan adalah multiplex nestedPolymerase Chain Reaction (PCR).

Tujuan: Mendeteksi T. gondii, CMV, dan HSV pada wanita hamil di Klinik Praktek Mandiri Bidan Anna Rohanah Kabupaten Bandung dengan metode multiplex nested PCR.

Metode: Teknik pengambilan sampel yang digunakan adalah quota sampling dengan jumlah sampel sebanyak 42 orang. Gen B1 dari T. gondii, MIEA dari CMV, dan Glikoprotein D dari HSV diamplifikasi menggunakan primer spesifik. Analisis data yang digunakan adalah teknik analisis deskriptif.

Hasil: Dari 42 orang wanita hamil, terdapat 3 orang $(7,14 \%)$ yang terinfeksi $T$. gondii dan 1 orang $(2,38 \%)$ yang mengalami koinfeksi CMV - HSV. Dua dari tiga wanita hamil dengan toxoplasmosis tidak menunjukkan gejala sedangkan wanita dengan koinfeksi CMV - HSV mengalami keputihan, sakit buang air kecil, gatal pada area genital, dan terdapat bintil pada mulutnya.

Kesimpulan: Metode multiplex nested PCR berhasil digunakan untuk mendeteksi infeksi T. gondii pada 3 orang wanita hamil dan koinfeksi CMV - HSV pada 1 orang wanita hamil di Klinik Praktek Mandiri Bidan Anna Rohanah Kabupaten Bandung.
\end{abstract}

Kata Kunci: Cytomegalovirus; Herpes Simplex Virus; Polymerase Chain Reaction; T. gondii

\section{ABSTRACT}

Background: One of the causes of high infant mortality in Bandung regency is congenital infections such as Toxoplasma gondii, Cytomegalovirus (CMV), and Herpes Simplex Virus (HSV). To reduce this number, a sensitive and specific detection method is required. One method that can be used is multiplex nested Polymerase Chain Reaction (PCR).

Objective: Detect T. gondii, CMV, and HSV in pregnant women at the Anna Rohanah Independently Practiceing Midwife, Bandung Regency using multiplex nested PCR method.

Methods: The sampling technique used quota sampling with a total sample of 42 people. Genes B1 from $T$. gondii, MIEA from CMV, and Glycoprotein D from HSV were amplified simultaneously. The data analysis used descriptive analysis technique.

Results: Of the 42 pregnant women, there were 3 people (7.14\%) infected with T. gondii and 1 person (2.38\%) who had CMV-HSV coinfection. Two out of three pregnant women with toxoplasmosis were asymptomatic, while women with CMV-HSV co-infection experienced vaginal discharge, painful urination, itching in the genital area, and nodules in her mouth.

Conclusion: The multiplex nested PCR method was successfully used to detect T. gondii infection in 3 pregnant women and CMV - HSV coinfection in 1 pregnant woman at the Anna Rohanah Independent Practice Clinic, Bandung Regency.

Keywords: Cytomegalovirus; Herpes Simplex Virus; Polymerase Chain Reaction; T. gondii

\Corresponding author: patriciagitanaully@gmail.com

Diajukan 3 Maret 2021 Diperbaiki 14 Januari 2022 Diterima 14 Januari 2022

https://jurnal.ugm.ac.id/jkesvo Published online February 28, 2021 


\section{PENDAHULUAN}

Kabupaten Bandung adalah salah satu kabupaten yang ada di Provinsi Jawa Barat, Indonesia. Kabupaten tersebut memiliki luas sebesar 1762,4 km2 dan penduduk sebanyak 3.717.291 jiwa (Badan Pusat Statistik Kabupaten Bandung, 2019). Padatnya penduduk di kabupaten tersebut menyebabkan timbulnya berbagai macam masalah, antara lain masalah kesehatan.

Salah satu masalah kesehatan yang dihadapi adalah angka kematian bayi yang masih tinggi. Berdasarkan data Dinas Kesehatan, angka kematian bayi di Kabupaten Bandung tahun 2016 mencapai 33,6 per 1000 kelahiran hidup (Dinas Kesehatan Kabupaten Bandung, 2018). Angka tersebut meningkat tiap tahun. Pada tahun 2016, dilaporkan jumlah kasus kematian bayi sebanyak 214 bayi. Sebanyak 18 kasus (8,14\%) kematian bayi di daerah tersebut disebabkan oleh infeksi kongenital.

Infeksi kongenital adalah infeksi yang terjadi pada bayi akibat tertular dari ibunya. Cara penularannya dapat melalui in utero, intrapartum, atau postnatal (Kamal et al., 2013; Pratama, 2018; Altaie \& Al-Attar, 2019). Ada beberapa patogen yang dapat menyebabkan infeksi kongenital, antara lain Toxoplasma gondii, Cytomegalovirus (CMV), dan Herpes Simplex Virus (HSV). Infeksi oleh ketiga patogen tersebut umumnya bersifat asimtomatik, namun signifikansi infeksinya dapat meningkat selama masa kehamilan (Kamal et al., 2013; Pratama, 2018; Sari, 2019).

Infeksi kongenital dapat menyebabkan kerusakan pada janin. Toxoplasmosis kongenital dapat menyebabkan keguguran, kerusakan visual, dan kerusakan saraf pada bayi seperti hidrosepalus, retardasi mental, cerebral calcification, serta chorioretinitis (Naully \& Supendi, 2020). CMV juga merupakan penyebab gangguan pendengaran, perkembangan saraf, retardasi mental, pneumonia, hepatitis, dan kelainan darah pada bayi (Kamal et al., 2013; Pratama, 2018). Organ janin yang paling sering mengalami kerusakan akibat infeksi CMV adalah paru-paru, pankreas, ginjal, dan hati (Dinc et al., 2010).

Menurut Kamal et al. (2013), sebanyak $50 \%$ bayi yang lahir dengan infeksi HSV akan mengalami penyakit yang menyebar ke seluruh tubuh dalam 9-11 hari setelah lahir dan sekitar $20 \%$ bayi yang terinfeksi akan mengalami infeksi lokal pada mata, mulut, atau kulit. Beberapa penelitian juga sudah membuktikan bahwa infeksi oleh ketiga patogen tersebut berkaitan dengan Bad Obstetric History (Kamal et al., 2013; Altaie \& Al-Attar, 2019).

Untuk menurunkan angka kematian dan kecacatan pada bayi maka pemeriksaan terhadap ketiga patogen tersebut perlu dilakukan pada wanita usia subur khususnya wanita hamil. Infeksi $T$. gondii, CMV, dan HSV umumnya dideteksi menggunakan uji serologi seperti Enzyme Linked Immunosorbent Assay (ELISA). Uji serologi mendeteksi keberadaan antibodi dalam darah sehingga sering kali menunjukkan hasil negatif palsu selama awal infeksi dan pada penderita imunodefisiensi (Bin Dajem \& Almushait, 2012; Rahumatullah et al., 2012).

Selain itu, ELISA juga dilaporkan dapat menunjukkan hasil positif palsu pada kasus infeksi CMV dan HSV (Dinc et al., 2010; Altaie \& Al-Attar, 2019). Oleh sebab itu, beberapa peneliti menyarankan penggunaan metode Polymerase Chain Reaction (PCR) untuk mendeteksi T. gondii, CMV dan HSV (Bourdin et al., 2014; Altaie \& Al-Attar, 2019).

Kamal et al., merekomendasikan metode PCR jenis multiplex untuk mendeteksi ketiga patogen tersebut secara bersamaan. PCR jenis ini dapat mengamplifikasi beberapa gen target secara bersamaan karena menggunakan beberapa primer dalam satu kali reaksi. Dalam penelitiannya, Yamamoto et al. (2020) berhasil 
meningkatkan sensitivitas dan spesifisitas metode multiplex PCR dalam mendeteksi 7 patogen penyebab infeksi kongenital dengan cara menggabungkannya dengan metode nested PCR.

Nested PCR adalah metode amplifikasi gen yang menggunakan dua tahap amplifikasi dengan sepasang primer inner dan sepasang primer outer. Yamamoto et al. (2020) berhasil mendeteksi B1 dari T. gondii, MIEA dari CMV, dan Glikoprotein D dari HSV menggunakan metode multiplex nested PCR. Meskipun demikian, pemeriksaan tersebut masih memiliki kekurangan karena menggunakan spesimen berupa cairan amnion dan cairan serebrospinal neonatal. Teknik pengambilan dua jenis spesimen tersebut lebih sulit dibandingkan dengan darah.

Salah satu klinik bersalin yang ada di Kabupaten Bandung adalah Klinik Praktek Mandiri Bidan Anna Rohanah. Berdasarkan observasi, setiap hari ada sekitar 20 - 30 wanita hamil yang berkunjung ke klinik tersebut. Karakteristik wanita hamil yang berkunjung juga cukup beragam. Oleh sebab itu, penelitian ini bertujuan untuk mendeteksi T. gondii, CMV, dan HSV pada spesimen darah dari wanita hamil di Klinik Praktek Mandiri Bidan Anna Rohanah Kabupaten Bandung menggunakan metode multiplex nested PCR.

\section{METODE}

Proses pengambilan sampel penelitian bekerja sama dengan Klinik Praktek Mandiri Bidan Anna Rohanah Kabupaten Bandung. Kriteria inklusi sampel penelitian yang digunakan adalah wanita hamil, berusia $20-45$ tahun, berdomisili di Kabupaten Bandung, dan telah setuju untuk ikut serta dalam penelitian ini dengan cara menandatangani informed consent. Wanita hamil yang tidak bersedia menandatangani informed consent termasuk ke dalam kriteria ekslusi. Teknik pengambilan sampel yang digunakan adalah quota sampling dengan jumlah sampel sebanyak 42 orang. Semua sampel penelitian diminta untuk mengisi formulir wawancara yang berisi pertanyaan terkait identitas, usia kehamilan, dan berbagai gejala klinis yang disebabkan oleh infeksi T. gondii, CMV, dan HSV.

Tabel 1. Karakteristik Primer (Yamamoto et al., 2020)

\begin{tabular}{|c|c|c|c|c|}
\hline No & Primer & Amplifikasi & Urutan DNA & $\begin{array}{c}\text { Ukuran } \\
\text { Amplikon (bp) }\end{array}$ \\
\hline 1 & B1 F1 & Tahap I & 5'-TGCACCTTTCGGACCTCAACAAC-3' & 284 \\
\hline 2 & B1 R1 & & 5'-TCGCCTCATTTCTGGGTCTACGT-3' & \\
\hline 3 & B1 F2 & Tahap II & 5'-AACGGGCGAGTAGCACCTGAGGAGA-3' & 115 \\
\hline 4 & B1 R2 & & 5'-TGGGTCTACGTCGATGGCATGACAACT-3' & \\
\hline 5 & MIEA F1 & Tahap I & 5'-CCAAGCGGCCTCTGATAACCAAGCAGCC-3' & 435 \\
\hline 6 & MIEA R1 & & 5'-CAGCACСАТССТССТСТTССТСТGG-3' & \\
\hline 7 & MIEA F2 & Tahap II & 5'-AGTGTGGATGACCTACGGGCCATCG-3' & 110 \\
\hline 8 & MIEA R2 & & 5'-GGTGACACCAGAGAATCAGAGGAGC-3' & \\
\hline 9 & Gli-D F1 & Tahap I & 5'-ATCCGAACGCAGCCCCGCTG-3' & 382 \\
\hline 10 & Gli-D R1 & & 5'-TCCGGCGGCAGCAGGGTGCT-3' & \\
\hline 11 & Gli-D F2 & Tahap II & 5'-GCGCCGTCAGCGAGGATAAC-3' & 280 \\
\hline 12 & Gli-D R2 & & 5'-AGCTGTATA(G/C)GGCGACGGTG-3' & \\
\hline
\end{tabular}

Deteksi ketiga patogen tersebut diawali dengan isolasi DNA. DNA diisolasi dari darah sampel penelitian menggunakan gSYNC ${ }^{\mathrm{TM}}$ DNA Extraction Kit. Isolasi DNA terdiri dari tiga tahap, yaitu pelisisan sel darah merah, pelisisan inti sel dan pengendapan protein, serta pengendapan dan rehidrasi DNA.
Kemurnian dan konsentrasi DNA hasil isolasi diukur menggunakan alat nanodrop.

Kondisi amplifikasi gen target yang digunakan mengacu pada penelitian Yamamoto et al. (2020) dengan sedikit modifikasi karena menggunakan sekuens primer yang sama (Tabel 1). Tahap 
denaturasi DNA dilakukan selama 15 menit pada suhu $95^{\circ} \mathrm{C}$. Amplifikasi dilakukan sebanyak 40 siklus yang terdiri dari denaturasi pada suhu $95^{\circ} \mathrm{C}$ selama 30 detik, annealing pada suhu $59^{\circ} \mathrm{C}$ selama 2 menit, dan elongasi pada suhu $72^{\circ} \mathrm{C}$ selama 1 menit. Langkah elongasi akhir dilakukan selama 5 menit pada suhu $72^{\circ} \mathrm{C}$. Volume total reaksi amplifikasi adalah $25 \mu \mathrm{l}$ yang terdiri dari $16,5 \mu \mathrm{l}$ Qiagen Multiplex PCR Master Mix; 2,5 $\mu$ l buffer $\mathrm{MgCl} 2$ 1X; $1 \mu \mathrm{l}$ primer forward $0,4 \mathrm{mM} ; 1 \mu \mathrm{l}$ primer reverse $0,4 \mathrm{mM} ; 1 \mu \mathrm{l}$ Taq DNA Polymerase $0,2 \mathrm{U} / \mu \mathrm{l}$; dan $3 \mu \mathrm{l}$ DNA hasil isolasi.

Pada proses tersebut digunakan tiga kontrol positif, yaitu DNA yang diisolasi dari darah orang yang telah didiagnosis terinfeksi T. gondii, CMV, dan HSV mengunakan ELISA. Selain itu, digunakan juga dua kontrol negatif yaitu air steril (ddH2O) dan DNA yang diisolasi dari darah orang sehat. Hasil amplifikasi gen divisualisasi dengan metode elektroforesis agarosa. Konsentrasi gel agarosa yang digunakan adalah $1.5 \%$.

Data hasil wawancara dan amplifikasi gen diolah dan dianalisis dengan menggunakan teknik statistik deskriptif. Frekuensi data dihitung dan disajikan dalam bentuk tabel serta grafik. Seluruh prosedur yang dilakukan dalam penelitian ini sudah sesuai kode etik dan disetujui oleh Komisi Etik Penelitian Kesehatan
Stikes Jenderal Achmad Yani dengan nomor surat 001/KEPK/I/2021.

\section{HASIL DAN PEMBAHASAN}

Pada penelitian ini berhasil dikumpulkan 42 orang wanita hamil yang telah memenuhi kriteria inklusi. Mayoritas sampel penelitian berusia dibawah 35 tahun dengan usia kehamilan beragam mulai dari 7 minggu sampai 39 minggu. Dari hasil wawancara diketahui bahwa $11,9 \%$ responden pernah mengalami keguguran, $7,14 \%$ merasakan sakit atau gatal pada area genital, dan 30,95\% mengalami keputihan.

Hasil elektroforesis menunjukkan bahwa DNA dari darah seluruh sampel penelitian berhasil diisolasi. Konsentrasi DNA yang berhasil diisolasi sekitar 84,9 808,65 $\mathrm{ng} / \mu \mathrm{l}$ dengan tingkat kemurnian yang cukup baik, yaitu antara 1,7 - 2,0 .

Pada hasil elektroforesis amplifikasi tahap pertama, terlihat adanya pita DNA yang terbentuk pada 4 sampel penelitian, yaitu sampel nomor 1, 9, 13, dan 15 (Gambar 1). Hasil amplifikasi tersebut dijadikan cetakan untuk proses amplifikasi yang kedua. Ukuran amplikon hasil amplifikasi tahap kedua lebih kecil dari amplikon tahap pertama. Hasil elektroforesis amplifikasi tahap kedua (Gambar 2) menunjukkan adanya pita DNA pada 4 sampel penelitian yang sama dengan hasil amplifikasi tahap pertama. 


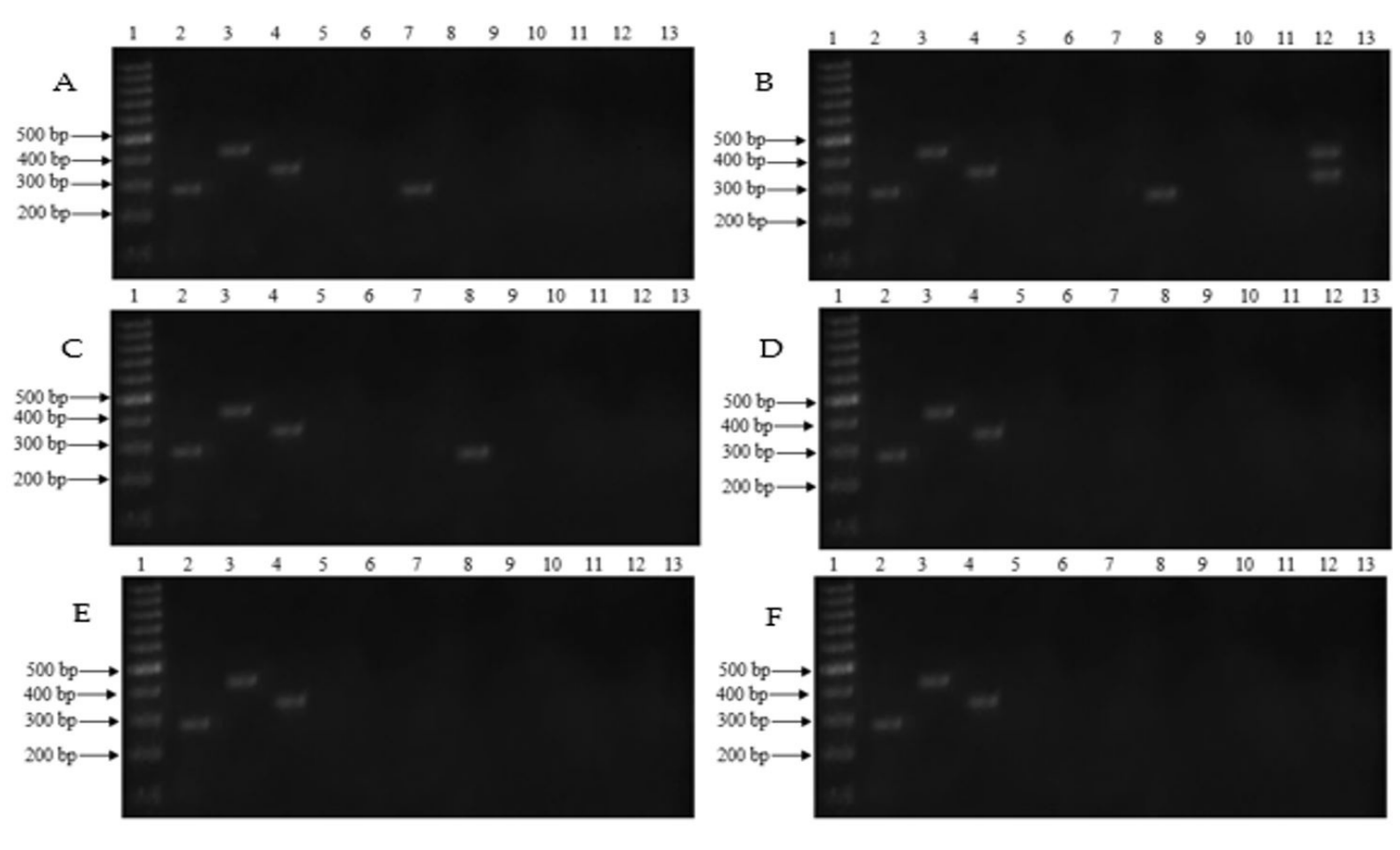

Gambar 1. Hasil Elektroforesis Amplifikasi Gen Tahap Pertama dari Darah Sampel. Lajur 1: Ladder Thermo Scientific 100 bp. Lajur 2: Kontrol Positif Gen B1. Lajur 3: Kontrol Positif Gen MIEA Lajur 4 Kontrol Positif Gen Glikoprotein D. Lajur 5 - 6: Kontrol Negatif. Lajur 7 - 13: (A) DNA Sampel Nomor 1 - 7 (B) Nomor 8 - 14 (C) Nomor 15 - 21 (D) Nomor 22 - 28 (E) Nomor 29 - 35 (F) Nomor 36 42.

Pada gambar 2(A) lajur 7 terlihat ada satu pita DNA yang berukuran $115 \mathrm{bp}$. Ukuran pita tersebut sama dengan kontrol positif pada lajur 2. Hasil tersebut menunjukkan bahwa pada darah sampel nomor 1 dapat terdeteksi gen B1 dari $T$. gondii.

Pada gambar 2(B) lajur 8 terlihat ada sebuah pita DNA dan pada lajur 12 ada dua buah pita DNA. Pita DNA hasil amplifikasi gen B1 dan gen MIEA sulit dibedakan pada hasil elektroforesis amplifikasi tahap kedua karena ukuran amplikonnya hampir sama yaitu $115 \mathrm{bp}$ dan 110 bp. Pada lajur 8 dan 12 nampak adanya pita DNA dengan ukuran yang sama, namun setelah mengamati hasil elektroforesis amplifikasi pertama dapat terlihat jelas bahwa kedua pita tersebut berbeda. Pada amplifikasi pertama, amplikon gen B1 dan MIEA memiliki ukuran yang berbeda yaitu 284 bp dan 435 bp.

Oleh sebab itu, dapat dipastikan bahwa pita DNA pada lajur 8 merupakan hasil amplifikasi gen B1 sedangkan pada lajur 12 merupakan amplifikasi gen MIEA. Hasil tersebut membuktikan bahwa sampel nomor 9 terinfeksi T. gondii sedangkan sampel nomor 13 mengalami koinfeksi CMV - HSV.

Pada gambar 2(C) lajur 8 juga terlihat adanya sebuah pita DNA berukuran 115 bp yang sama dengan kontrol positif $T$. gondii. Seluruh hasil pemeriksaan ini valid karena sudah menggunakan kontrol positif dan negatif yang sesuai. Proses amplikasi gen berlangsung secara spesifik. Hal ini dibuktikan dengan tidak adanya smear atau pita DNA yang terbentuk pada kontrol negatif. 

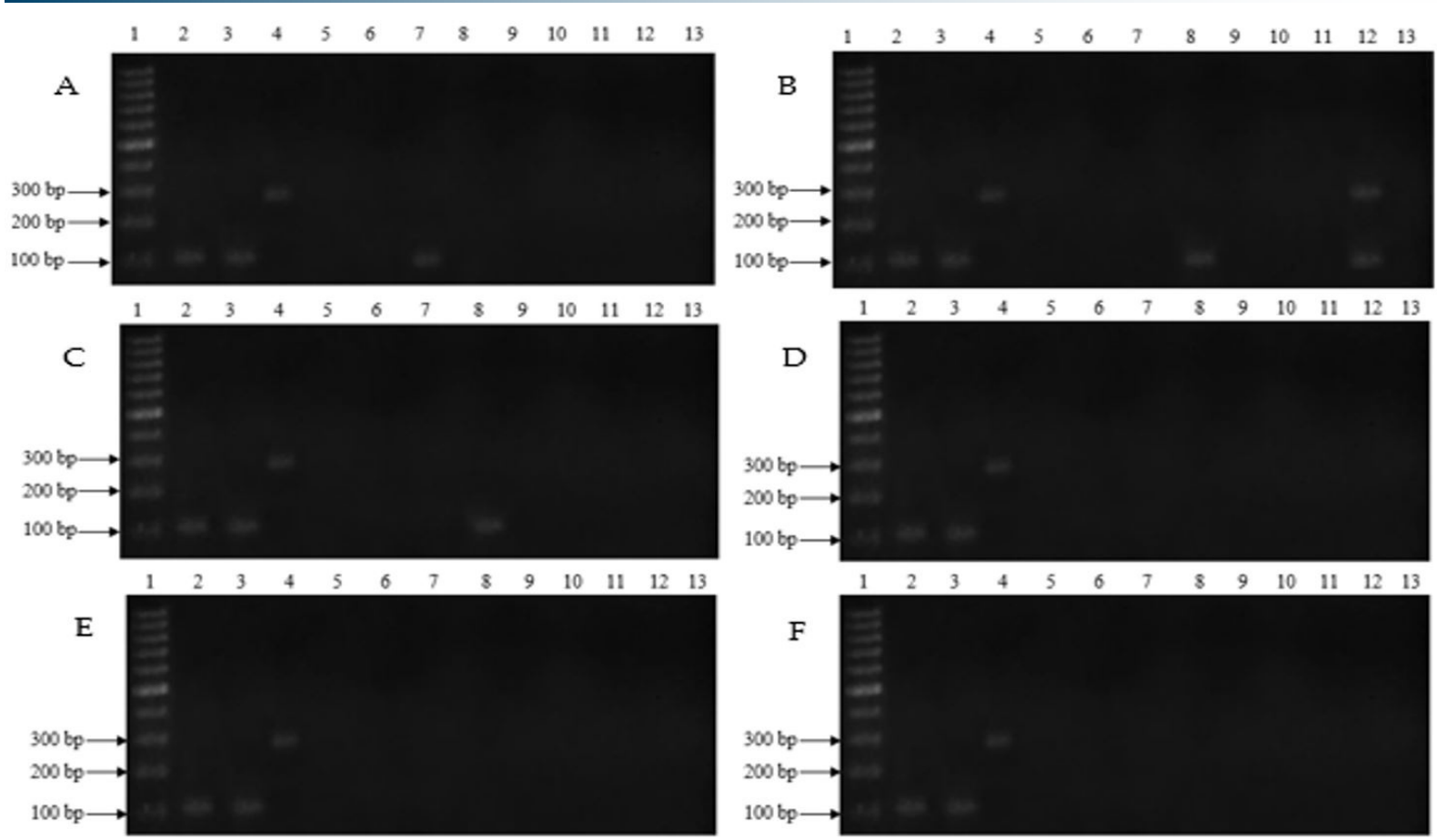

Gambar 2. Hasil Elektroforesis Amplifikasi Gen Tahap Kedua dari Darah Sampel. Lajur 1: Ladder Thermo Scientific 100 bp. Lajur 2: Kontrol Positif Gen B1. Lajur 3: Kontrol Positif Gen MIEA Lajur 4 Kontrol Positif Gen Glikoprotein D. Lajur 5 - 6: Kontrol Negatif. Lajur 7 - 13: (A) DNA Sampel Nomor 1 - 7 (B) Nomor 8 - 14 (C) Nomor 15 - 21 (D) Nomor 22 - 28 (E) Nomor 29 - 35 (F) Nomor 36 42.

Berdasarkan hasil pemeriksaan laboratorium dapat diketahui bahwa terdapat 3 orang $(7,14 \%)$ wanita hamil yang terinfeksi $T$. gondii dan 1 orang $(2,38 \%)$ yang mengalami koinfeksi CMV HSV (Gambar 3). Kedua wanita hamil yang mengalami toxoplasmosis tidak menunjukkan gejala klinis (Tabel 2). Hanya ada 1 orang yang mengaku pernah mengalami keguguran, keputihan, dan sakit pada pinggang bagian bawah. Ada kemungkinan keguguran pada kehamilan wanita tersebut disebabkan oleh T. gondii namun wanita tersebut belum pernah melakukan pemeriksaan laboratorium sebelumnya.

Wanita yang mengalami koinfeksi CMV-HSV juga mengaku pernah mengalami keputihan, sakit ketika buang air kecil, gatal pada area genital, dan terdapat bintil pada bagian mulutnya. Hasil yang didapatkan dalam penelitian ini sudah disampaikan kepada semua sampel penelitian. Keempat orang wanita yang terinfeksi diberikan rujukan ke dokter spesialis untuk mendapatkan pengobatan yang tepat.

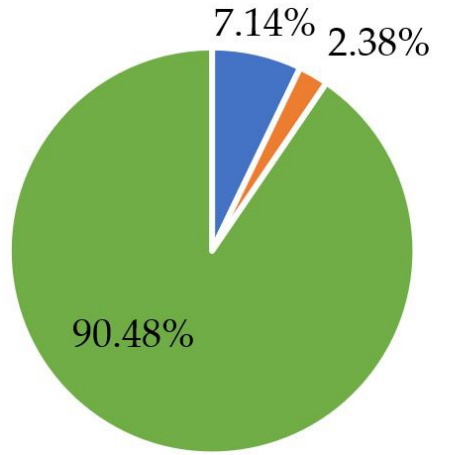

- Toxoplasma gondii

- Cytomegalovir us - Herpes Simplex Virus

- Tidak Terinfeksi

Gambar 3. Persentase Wanita Hamil di Kabupaten Bandung yang Terinfeksi T. gondii, CMV, dan HSV.

Infeksi kongenital yang disebabkan oleh T. gondii, CMV dan HSV sebenarnya dapat dideteksi menggunakan uji serologi, namun memiliki beberapa kekurangan. Liu et al. (2015) melaporkan bahwa uji serologi sering menunjukkan hasil negatif palsu pada awal infeksi T. gondii karena adanya window periode selama 1-2 minggu.

Hasil negatif palsu dalam uji serologi T. gondii, CMV, dan HSV juga sering ditemui pada orang yang mengalami gangguan sistem imun karena tubuhnya lambat atau gagal memproduksi antibodi (Bin Dajem \& Almushait, 2012; Coisel et al., 2012; Rajput et al., 2018). Selain itu, uji 
Pemanfaatan Multiplex Nested Polymerase Chain Reaction...

serologi dapat menunjukkan hasil positif palsu pada orang yang mengalami Systemic Lupus Erythematosus (SLE),
Antiphospholipid Syndrome (APS), dan Rheumatoid Arthritis (De Carolis et al., 2018).

Tabel 2. Karakteristik Sampel Penelitian.

\begin{tabular}{|c|c|c|c|c|c|c|}
\hline \multirow{2}{*}{ No } & \multirow{2}{*}{ Variabel } & \multirow{2}{*}{ Total (n) } & \multicolumn{2}{|c|}{ Terinfeksi T. gondii } & \multicolumn{2}{|c|}{ Koinfeksi CMV-HSI } \\
\hline & & & $\mathbf{n}$ & $\%$ & $\mathbf{n}$ & $\%$ \\
\hline & Jumlah Sampel & 42 & 3 & 7,14 & 1 & 2,38 \\
\hline & Usia Subjek & & & & & \\
\hline & a. $21-25$ tahun & 12 & 1 & 8,33 & 0 & 0 \\
\hline & b. $26-30$ tahun & 19 & 2 & 10,52 & 0 & 0 \\
\hline & c. $31-35$ tahun & 8 & 0 & 0 & 1 & 12,5 \\
\hline & d. $36-40$ tahun & 2 & 0 & 0 & 0 & 0 \\
\hline & e. $41-45$ tahun & 1 & 0 & 0 & 0 & 0 \\
\hline \multicolumn{7}{|c|}{ 3. Usia Kehamilan } \\
\hline & a. Trimester 1 & 11 & 2 & 18,18 & 1 & 9,09 \\
\hline & b. Trimester 2 & 17 & 1 & 5,88 & 0 & 0 \\
\hline & c. Trimester 3 & 14 & 0 & 0 & 0 & 0 \\
\hline \multicolumn{7}{|c|}{ 4. Memiliki Anak } \\
\hline & a. Ya & 29 & 0 & 0 & 1 & 3,44 \\
\hline & b. Tidak & 13 & 3 & 23,07 & 0 & 0 \\
\hline \multicolumn{7}{|c|}{ 5. Keguguran } \\
\hline & a. Ya & 5 & 2 & 40 & 0 & 0 \\
\hline & b. Tidak & 37 & 1 & 2,7 & 1 & 2,7 \\
\hline \multicolumn{7}{|c|}{ 6. Sakit atau gatal pada area genital } \\
\hline & a. Ya & 3 & 0 & 0 & 1 & 33,33 \\
\hline & b. Tidak & 39 & 0 & 0 & 0 & 0 \\
\hline \multicolumn{7}{|c|}{ 7. Keputihan } \\
\hline & a. Ya & 13 & 2 & 15,38 & 1 & 7,69 \\
\hline & b. Tidak & 29 & 1 & 3,44 & 0 & 0 \\
\hline \multicolumn{7}{|c|}{ 8. Sakit ketika buang air kecil } \\
\hline & a. Ya & 1 & 0 & 0 & 1 & 100 \\
\hline & b. Tidak & 41 & 0 & 0 & 0 & 0 \\
\hline \multicolumn{7}{|c|}{ 9. Bintil putih pada mulut atau hidung } \\
\hline & a. Ya & 1 & 0 & 0 & 1 & 100 \\
\hline & b. Tidak & 41 & 0 & 0 & 0 & 0 \\
\hline \multicolumn{7}{|c|}{ 10. Sakit pungoung bagian bawah } \\
\hline & a. Ya & 12 & 1 & 8,33 & 0 & 0 \\
\hline & b. Tidak & 30 & 2 & 6,67 & 1 & 3,33 \\
\hline
\end{tabular}

Penelitian ini berhasil membuktikan bahwa metode multiplex nested PCR dapat dijadikan metode alternatif untuk mendeteksi T. gondii, CMV, dan HSV dari spesimen darah. PCR merupakan metode untuk mengamplifikasi urutan DNA tertentu dengan bantuan enzim DNA Polimerase secara in vitro. PCR terdiri dari beberapa jenis, yaitu PCR konvensional, nested PCR, Reverse Transcription PCR (RT PCR), multiplex PCR, dan Real Time PCR atau disebut juga quantitative PCR (qPCR) (Boesenberg-Smith et al., 2012). Metode PCR memiliki sensitivitas dan spesifisitas yang baik, namun pemilihan jenisnya tergantung pada kebutuhan.

PCR konvensional dan nested PCR dapat juga digunakan untuk mendeteksi
T. gondii, CMV, dan HSV, namun memiliki kelemahan. Satu kali reaksi PCR konvensional dan nested PCR hanya dapat mendeteksi satu jenis gen target dari satu patogen sehingga untuk mendeteksi ketiga patogen tersebut dibutuhkan tiga kali reaksi. Hal tersebut akan berdampak pada jumlah reagen, biaya, dan waktu pengerjaan. Oleh karena itu, multiplex PCR dapat dijadikan alternatif untuk mendeteksi lebih dari satu jenis gen dari berbagai patogen.

Metode multiplex PCR dapat digabungkan dengan nested PCR untuk mendapatkan hasil pemeriksaan yang lebih spesifik dibandingkan metode gabungan multiplex dan konvensional PCR (Yamamoto et al., 2020). Meskipun 
demikian, metode tersebut masih memiliki keterbatasan jika dibandingkan qPCR. Metode multiplex nested PCR hanya dapat menunjukkan hasil pemeriksaan secara kualitatif (positif terinfeksi atau negatif) sedangkan qPCR dapat menunjukkan hasil pemeriksaan secara kuantitatif dengan memberikan data jumlah gen target dari patogen yang menginfeksi pasien.

Seluruh proses pemeriksaan dalam penelitian ini berlangsung dengan baik, mulai dari isolasi DNA hingga visualisasi hasil amplifikasi. Konsentrasi DNA hasil isolasi sudah memenuhi syarat minimal yang dapat digunakan untuk analisis PCR yaitu $100 \mathrm{ng} / \mu \mathrm{l}$ (Integrated DNA Technologies, 2011). Nilai kemurian DNA ada yang dibawah 1.8.

Dari hasil tersebut diketahui bahwa ada beberapa DNA hasil isolasi yang masih terkontaminasi dengan protein tetapi masih dapat digunakan untuk analisis PCR. Beberapa sumber menuliskan nilai kemurnian DNA yang baik adalah 1,8 - 2,0 (Boesenberg-Smith et al., 2012; Gupta, 2019), namun ada pula sumber yang menyatakan bahwa DNA dengan nilai kemurnian 1,7 - 2,0 dapat digunakan untuk analisis PCR (Piskata et al., 2019).

Hasil penelitian ini juga sesuai dengan penelitian Saadatnia dan Golkar (2012) yang menyatakan bahwa mayoritas toxoplasmosis pada wanita usia subur tidak menimbulkan gejala. Selain itu, kasus koinfeksi CMV - HSV yang ditemukan pada penelitian ini juga pernah dilaporkan oleh Chiu et al. (2013) dan Xu et al. (2015). Pada penelitiannya, Xu et al. (2015) menuliskan bahwa koinfeksi CMV umumnya terjadi pada pasien immunocompromised. Hal tersebut bisa juga terjadi pada wanita yang menjadi sampel penelitian ini namun terbukti metode multiplex nested PCR yang digunakan berhasil mendeteksi infeksi tersebut. Hasil ini sesuai dengan penelitian Yamamoto et al. (2020) yang menyatakan bahwa metode multiplex nested PCR menunjukkan tingkat deteksi 4,6 kali lebih tinggi dari uji serologi.

\section{PENUTUP}

Melalui penelitian ini dapat disimpulkan bahwa di Klinik Praktek Mandiri Bidan Anna Rohanah Kabupaten Bandung terdapat 3 orang $(7,14 \%)$ wanita hamil yang terinfeksi $T$. gondii dan 1 orang $(2,38 \%)$ wanita hamil yang mengalami koinfeksi CMV - HSV. Metode multiplex nested PCR terbukti dapat digunakan sebagai metode alternatif untuk mendeteksi patogen penyebab infeksi kongenital pada spesimen darah dari wanita hamil. Bagi wanita pasangan usia subur disarankan untuk melakukan pemeriksaan seperti ini secara dini untuk mencegah infeksi kongenital pada bayi.

\section{DAFTAR PUSTAKA}

Altaie, A., \& Al-Attar, M. (2019). Molecular Diagnosis of TORCH Infection of Pregnant Women in Iraq. IJMS, 2, 5868.

Badan Pusat Statistik Kabupaten Bandung. (2019). Statistik Daerah Kabupaten Bandung 2019. Badan Pusat Statistik Kabupaten Bandung.

Bin Dajem, S. M., \& Almushait, M. A. (2012). Detection of Toxoplasma gondii DNA by PCR in blood samples collected from pregnant Saudi women from the Aseer region, Saudi Arabia. Annals of Saudi Medicine, 32(5), 507512. https://doi.org/10.5144/02564947.2012.14.7.1200

Boesenberg-Smith, K. A., Pessarakli, M. M., \& Wolk, D. M. (2012). Assessment of DNA Yield and Purity: An Overlooked Detail of PCR Troubleshooting. Clinical Microbiology Newsletter, 34(1), 1-6. https://doi.org/ 10.1016/j.clinmicnews.2011.12.002

Bourdin, C., Busse, A., Kouamou, E., Touafek, F., Bodaghi, B., Le Hoang, P., Mazier, D., Paris, L., \& Fekkar, A. (2014). PCR-Based Detection of 
Toxoplasma gondii DNA in Blood and Ocular Samples for Diagnosis of Ocular Toxoplasmosis. Journal of Clinical Microbiology, 52(11), 39873991. https://doi.org/10.1128/ JCM.01793-14

Chiu, H., Chang, C., Hsiao, C., \& Wang, L. (2013). Concurrent Cytomegalovirus and Herpes Simplex Virus Infection in Pemphigus Vulgaris Treated with Rituximab and Prednisolone. Acta Dermato Venereologica, 93(2), 200-201. https://doi.org/10.2340/00015555-1429

Coisel, Y., Bousbia, S., Forel, J.-M., Hraiech, S., Lascola, B., Roch, A., Zandotti, C., Million, M., Jaber, S., Raoult, D., \& Papazian, L. (2012). Cytomegalovirus and Herpes Simplex Virus Effect on the Prognosis of Mechanically Ventilated Patients Suspected to Have Ventilator-Associated Pneumonia. PLoS ONE, 7(12), e51340. https:// doi.org/10.1371/journal.pone.0051340

De Carolis, S., Tabacco, S., Rizzo, F., Perrone, G., Garufi, C., Botta, A., Salvi, S., Benedetti Panici, P., \& Lanzone, A. (2018). Association between falsepositive TORCH and antiphospholipid antibodies in healthy pregnant women. Lupus, 27(5), 841-846. https://doi.org/ 10.1177/0961203317741564

Dinas Kesehatan Kabupaten Bandung. (2018). Profil Kesehatan Tahun 2018. Dinas Kesehatan Kabupaten Bandung.

Dinc, B., Bozdayi, G., Biri, A., Kalkanci, A., Dogan, B., Bozkurt, N., \& Rota, S. (2010). Molecular detection of cytomegalovirus, herpes simplex virus 2, human papillomavirus 16-18 in Turkish pregnants. The Brazilian Journal of Infectious Diseases: An Official Publication of the Brazilian Society of Infectious Diseases, 14(6), 569-574. https://doi.org/10.1016/s14138670(10)70114-8

Gupta, N. (2019). DNA extraction and polymerase chain reaction. Journal of
Cytology, 36(2), 116. https://doi.org/ 10.4103/JOC.JOC_110_18

Integrated DNA Technologies. (2011). Breaking PCR: A Systematic Investigation of Intentional Violations of a Basic Polymerase Chain Reaction Amplification Protocol. Integrated DNA Technologies.

Kamal, S. A. A., Awadh, R. M. J., \& AlMarzoqi, A. H. M. (2013). Genetic Study of TORCH Infections in Women with Bad Obstetric History: Multiplex Polymerase Chain Reaction for Detection of Common Pathogens and Agents of Congenital Infections. Journal of Biology, 7.

Liu, Q., Wang, Z.-D., Huang, S.-Y., \& Zhu, X.-Q. (2015). Diagnosis of toxoplasmosis and typing of Toxoplasma gondii. Parasites $\mathcal{E}$ Vectors, 8(1), 292. https://doi.org/ 10.1186/s13071-015-0902-6

Naully, P. G., \& Supendi, S. A. (2020). Detection of B1 gene as Toxoplasmosis marker in women of childbearing age in West Bandung Regency, Indonesia. Jurnal Teknologi Laboratorium, 9(2), 168-175. https:// doi.org/10.29238/ teknolabjournal.v9i2.204

Piskata, Z., Servusova, E., Babak, V., Nesvadbova, M., \& Borilova, G. (2019). The Quality of DNA Isolated from Processed Food and Feed via Different Extraction Procedures. Molecules, 24(6), 1188. https://doi.org/ 10.3390/molecules24061188

Pratama, B. F. (2018). Infeksi Cytomegalovirus Kongenital. Jurnal Kesehatan Melayu, 1(2), 114. https:// doi.org/10.26891/jkm.v1i2.2018.114117

Rahumatullah, A., Khoo, B. Y., \& Noordin, R. (2012). Triplex PCR using new primers for the detection of Toxoplasma gondii. Experimental Parasitology, 131(2), 231-238. https:// doi.org/10.1016/j.exppara.2012.04.009

Rajput, R., Denniston, A. K., \& Murray, P. 
I. (2018). False Negative Toxoplasma Serology in an Immunocompromised Patient with PCR Positive Ocular Toxoplasmosis. Ocular Immunology and Inflammation, 26(8), 1200-1202. https://doi.org/ 10.1080/09273948.2017.1332769

Saadatnia, G., \& Golkar, M. (2012). A review on human toxoplasmosis. Scandinavian Journal of Infectious Diseases, 44(11), 805-814. https:// doi.org/10.3109/00365548.2012.693197

Sari, R. D. P. (2019). Kehamilan dengan Infeksi TORCH. JK UNILA, 3(1), 176181.

Xu, H., Chen, S., Lin, Q., Zhou, H., Huang, C., Lin, J., Xie, W., Chen, K., Zhou, D., Ma, W., Ma, F., \& Xue, C. (2015).
Double encephalitis with herpes simplex virus type II and cytomegalovirus in an elder Chinese: A case report. Neuropsychiatric Disease and Treatment, 2833. https://doi.org/ 10.2147/NDT.S92366

Yamamoto, L., Filho, A. G. A., Queiroz, J. A., de Carvalho, M. H. B., Rodrigues, J. C., Kanunfre, K. A., Francisco, R. P. V., \& Okay, T. S. (2020). Performance of a Multiplex Nested Polymerase Chain Reaction in Detecting 7 Pathogens Containing DNA in Their Genomes Associated With Congenital Infections. Archives of Pathology $\mathcal{E}$ Laboratory Medicine, 144(1), 99-106. https://doi.org/10.5858/arpa.20180544-OA 